\title{
Q
}

\section{A Space of Performing Citizenship: The Gängeviertel in Hamburg}

\author{
Michael Ziehl
}

A performative perspective on citizenship allows us to overcome conventional views of citizenship and points a spotlight on the question of how people articulate claims as rights (Isin 2017). In this chapter, I will focus on this question by using the example of the Gängeviertel - the abandoned quarter in the middle of Hamburg that was occupied by an activist initiative in 2009. Since then, the Gängeviertel activists continue to publicly articulate claims concerning the self-management of the place and the right to the city. They apply these practices in situ, and therewith continuously produce a space of performing citizenship. I will illustrate some of these practices and point out how they contribute to an effective articulation of claims with the help of a spatial entanglement of the public to the place. With reference to Lefebvre's concept of the production of social space, I will show thereby that place-specific conditions play a particular and important role.

\section{Ziehl (ه)}

Graduate Program Performing Citizenship, HafenCity University Hamburg, Hamburg, Germany

e-mail: kontakt@urban-upcycling.de

(C) The Author(s) 2019

P. Hildebrandt et al. (eds.), Performing Citizenship, Performance

Philosophy, https://doi.org/10.1007/978-3-319-97502-3_11 


\section{History, Materiality and Characteristics}

The Gängeviertel is a historic ensemble of thirteen houses, situated in the city center of Hamburg. Although it is heritage-protected, the city of Hamburg sold the abandoned quarter and permitted substantial amounts of demolition, largely to enable the construction of luxury flats, offices and commercial space. While the demolition was being planned, two artists' collectives were using storefronts in the Gängeviertel as studio spaces. When they heard about the plans they decided to mobilize against it. As a result, in August 2009 about 200 artists, cultural workers and activists occupied the Gängeviertel in protest against the neoliberal policy of the city government. They demanded the creation of affordable working and residential space in the city, the preservation of the historical buildings, as well as a more participative urban development policy. The occupationor cultural appropriation ${ }^{1}$ as the activists prefer to call it-gained huge publicity and a lot of people sympathized with the activists. Due to public pressure, and after intense negotiations, four months later, the Senate of Hamburg decided to buy the Gängeviertel back from the investor. This was the start of official cooperation between the occupiers and the city administration of Hamburg; both began to acquire a development concept for the Gängeviertel. In essence, the new idea provides for the gradual renovation of the thirteen buildings and the creation of publicly funded social housing, studios, and cultural spaces on about $7500 \mathrm{~m}^{2}$ of floor space. The entire cost of the renovation was earmarked at 20 million Euros.

However, the occupiers did not wait until an agreement with the city government was achieved; they already began to refurbish and to adapt the thirteen houses informally. On the upper floors studios and workshops were established, while rooms on the ground floors were prepared for semi-public usage-such as cafés, galleries and venues. Today, the Gängeviertel is a vibrant and non-commercial urban space that functions on the basis of openness, voluntary work, collectives and grass-root democratic structures. Everybody who is capable and interested can be involved in the decision-making processes and the organizing of groups, take-on tasks, start a new undertaking or apply for free rooms. These characteristics depend on the self-management ${ }^{2}$ of the place and became established after the occupation. Since the renovation began, the Gängeviertel activists increasingly fear that it is the aim of the city government to normalize the place and its management by cleaning up its unique appearance and 
installing a professional housing administration. Furthermore, they criticize the fact that cooperation is not carried out openly and honestly by the municipality and that the mandated redevelopment agency gives too little regard to their demands concerning the renovation measures. The municipality largely ignored these problems and proceeded as scheduled in order to remain on-time with the renovation process. Consequently, the Gängeviertel refused further collaboration and, in February 2015, the cooperation was close to failure. All project planning stopped and the two parties started to negotiate over the implementation of further renovations, as well as the continuation of the proposals for self-management from the initiative. ${ }^{3}$

\section{Claims, Conflicts and Citizenship}

Notions of citizenship are diverse, as critical citizenship studies have shown. As Engin Isin points out, 'citizenship, while typically understood as a legal status of membership in the state, if not the nation-state, became increasingly defined as practices of becoming claim-making subjects in and through various sites and scales' (Isin 2008, p. 16). Thus, citizenship derives not only from someone's status of having rights but also from someone's performance in claiming rights. This performative take on citizenship 'allows us to appreciate that how people perform citizenship plays an important role in contesting and constructing citizenship and attaching meanings to rights' (Isin 2017, p. 501). Before examining more closely how the Gängeviertel activists perform their claims, I will consider the question of how far these claims are connected to issues of citizenship. Accordingly, it is helpful to distinguish formal and substantive citizenship, as James Holston and Arjun Appadurai did with regard to ongoing renegotiations of citizenship within cities. As they put it, 'formal refers to membership in the nation-state and the substantive to the array of civil, political, socio-economic, and cultural rights people possess and exercise' (Holston and Appadurai 1999, p. 4) [emphasis of the author]. The struggle of the Gängeviertel activists-who mostly are formal citizens of Germany or other nation-states-is about substantive citizenship whereby they articulate several claims concerning two distinctive scales.

On the local scale of the Gängeviertel, the activists demand the continuation of self-management for the time following the renovation. For them, self-management is a necessary requirement so that the Gängeviertel functions as an open and cultural place to live and work. Furthermore, 
they see it as the only guarantee that the place cannot be sold later on. Concerning the renovation, they urge more participation; they wish to take more responsibility and make greater contribution within the process because they are not satisfied with outcomes concerning usability of the buildings and aspects of heritage protection. To actually meet these claims, the city government would have to adjust the existing renovation concept and to assign property rights to the Gängeviertel cooperative. ${ }^{4}$ That would entail a relinquishment of control over the place and its development. Contrary to this, the city government seeks to keep control to ensure the finalization of the renovation and the long-term development of the place. City representatives argue that they cannot adapt the proposed renovation procedure due to administrative directives and are obliged to verify the accurate application of public investments. Additionally, the government would have to accept a shortfall in receipts, as the activists of the Gängeviertel are not willing and not able to pay the actual market value. City representatives assert that giving such advantage is not compatible with the principle of equal treatment. Altogether, claims of the Gängeviertel activists on a local scale challenge governance practices, municipal directives, and property rights concerning the place. ${ }^{5}$

On the city scale of Hamburg, the Gängeviertel activists claim the right to the city as a universal right for all urban dwellers. ${ }^{6}$ To put this claim into practice they contest the policy of the city government and work against its growth-oriented and enterprise-friendly agenda. Moreover, they are proactive in supporting self-organized social and housing projects; they campaign against the privatization of public property, real estate speculation, as well as for the rights of refugees. Alongside many initiatives of the 'Right to the City Network' in Hamburg, the Gängeviertel is part of a political voice in the city. ${ }^{7}$

\section{Successes and Public Relations}

The activists of the Gängeviertel have achieved some remarkable successes on both local and city scale. Only a few days after the occupation, they signed a contract allowing them to use the abandoned houses temporarily without paying rent. Four months after the occupation, they achieved the buy-back of the Gängeviertel. Shortly thereafter, the city government announced the abolition of the Höchstgebotsverfahren, according to which public real estate was sold to the highest bidder without regard to the concept of usage. In 2010, an association and a cooperative were founded 
by the activists, as legal structures for self-management, making legal entities available as contracting partners with the municipality. In 2011 , the activists of the Gängeviertel enforced a cooperation agreement stating terms of rights and duties during the renovation process, ${ }^{8}$ and in 2015 , they enforced a general rental agreement for the first three renovated buildings. Notably, the agreement to halt the planning process can be seen as an achievement for them, because it was their aim to stop the ongoing process in order to allow for adjustments and further negotiations.

These successes are the result of intense debates, a huge amount of organization and paper work, the advice of experienced consultants, solidarity among the 'Right to the City' network, and huge support and backing from a substantial part of the public. From the cultural appropriation until today, the Gängeviertel activists act with respectful regard to public opinion. They know that, in negotiations with the municipality, the public sits at the table and that media and social networks play an important role as distributors and co-creators of public opinion. Thus, actions of claimmaking are designed with a careful view to media coverage and public relations. ${ }^{9}$ As Gesa Ziemer pointed out, with reference to Nancy Fraser, the activists of the Gängeviertel never aimed to create a counter-public as is typical for many occupiers (Ziemer 2014). Rather, they understand the public sphere 'as a vehicle for marshaling public opinion as a political force' (Fraser 2007). To mobilize a wide range of the public sphere, they argue that the self-management of the Gängeviertel is to the benefit of many people in Hamburg, primarily because its structural openness and cultural program form an enrichment for city dwellers generally-not only for those who are interested in art and culture or would like to become active in self-organized structures. They highlight that the Gängeviertel is accessible for marginalized urban dwellers, and that they take care to force the municipality to put heritage protection in place. By doing so, to some degree, they enact themselves as representatives of social and cultural public interests and ask the question: who is in position to represent these interests-politicians, as elected representatives of those who have the right to vote? Or activists like themselves, who proactively get involved in public issues? In the following, I introduce some practices to illustrate how demands of the Gängeviertel activists are performed publicly, particularly at the place in question. 


\section{Practices of Performing Citizenship}

Cultural appropriation of the Gängeviertel can be seen as the starting point for the development of place-specific practices of performing citizenship. It was organized by a core group of activists who planned the appropriation, explored the place, and secretly prepared exhibitions and installations in the houses. The 'happening' was announced as a courtyard festival throughout the city, and thousands of people came to celebrate in the narrow passageways among outdoor bars and exhibitions. One by one, activists opened doors to the visitors but made sure to stay unidentifiable as responsible persons. Instead of barricading the houses, they were made accessible and everybody was invited to become a part of the appropriation process. This generated a positive response from a broad spectrum of Hamburg society and the media. After reports in the local media, the international press also picked up on the subject. Following the first reports, politicians began to speak up. Most expressed their understanding for the reasons behind the action and signaled their willingness to engage in speaking for the concerns of the initiative. Out of this experience the

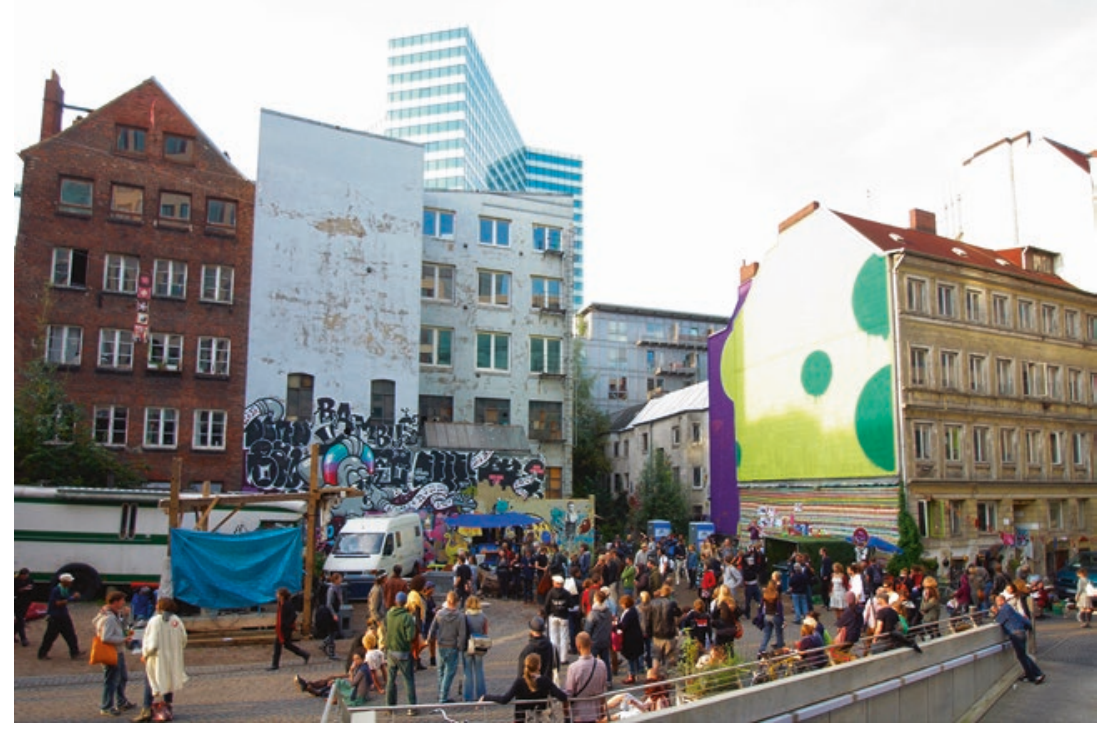

Fig. 1 Gängeviertel 2nd anniversary. (Photo: Franzi Holz, August 2011) 
activists constantly progressed in arranging cultural events. One can say that they continued with the cultural appropriation but stabilized this process while establishing organizational structures. Currently, exhibitions, concerts, film showings, readings and public discussions take place somewhere in the Gängeviertel nearly every day. Hundreds of visitors come every week and take advantage of the mostly free and open-to-all events and activities. The cultural program is the key means for the Gängeviertel activists to keep the place vibrant, gain sustained public awareness and increase the popularity of the place (Fig. 1).

During the G20 summit in July 2017, the Gängeviertel was converted into a 'Free Oasis' with outdoor concerts, exhibitions and rest areas, together with an infrastructure to supply protesters with food, first aid and information about ongoing police and protest action. Demonstrations in the Gängeviertel were prohibited by the court during the G20 summit because it was located in the official safety zone, where the right to free assembly was suspended; police forces had the area surrounded over and over again in order to prevent blockades that might obstruct diplomatic convoys passing nearby. Nevertheless, hundreds of activists from all around Europe used the place to organize peaceful protests and to recover from actions in the streets of Hamburg. Shortly after the summit, the Gängeviertel activists publicly declared their solidarity with activists of the Rote Flora, who were blamed by politicians as being responsible for violent confrontations between radical left activists and the police force. As a consequence, local politicians moved to cut official funding for the Gängeviertel, and its activists feared that the administration could stop the negotiations about further renovation. Despite this, the Gängeviertel activists maintained their declaration of solidarity and sustained critique on the G20 Summit. Many creative protest actions were supported and organized by them, raising their public profile-like a rave demonstration with around 20,000 protesters and a zombie-like performance called ' 1000 Gestalten' that gained wide attention in international media.

The anniversary of the cultural appropriation is celebrated with a large program over several days. For this event, the place is transformed into a festival area with installations, temporary bars and stages. The organization is partly chaotic, but works on a foundation of experience and spontaneity together with a sense of responsibility from most of the visitors. With this yearly spectacle, the Gängeviertel activists publicly demonstrate their popularity and general backing in the city society. When the cooperation process with the municipality was close to failure in 2015 , the 
Gängeviertel organized a solidarity concert with the Goldenen Zitronenan experimental punk band famous for its progressive music and critical lyrics. The band played in one of the passageways to underline the demand for self-management by the Gängeviertel activists and marked the starting point of a solidarity campaign that was undersigned by hundreds of artists and cultural workers from all around the world. ${ }^{10}$

There is a continual practice of hosting conferences, public workshops and discussion events concerning political and social issues. Some are selforganized, others are arranged by non-profit organizations and activist groups. In this way, the activists of the Gängeviertel attract a critical audience, promote political dialogues and demonstrate its connectedness to political activist networks and scholars. Inspired by such events, in April 2015, I organized a symposium as a practical part of my research about the Gängeviertel cooperation process. A workshop, conducted with city representatives and activists, took place to get insight into the aims and interests of the stakeholders, and to figure out common ground so to further improve the process. It became clear that both sides have different aims and ideas concerning the future development. City representatives see it primarily as a determined construction process with a clear ending, resulting in affordable spaces for cultural production and living in the city center. In contrast, the Gängeviertel activists want to maintain the political significance of the place and maintain its openness for spontaneous developments. After the workshop, a public debate took place titled 'Cooperations between Municipalities and Citizen Initiatives'. It was my aim to involve the city representatives in a public debate about the cooperation and development process, but they refused to take part as panelists. Those who did come to the discussion highlighted that they took part as citizens and did not speak publicly. It seems that city representatives fear the nature of the public the Gängeviertel creates and prefer to avoid public debates on-site.

\section{Place, Stage and Scene}

To connect these practices to the concept of performing citizenship, as it is promoted in this chapter, I again refer to Engin Isin. He contrasts "“activist citizens" with "active citizens" [...]. While activist citizens engage in writing scripts and creating the scene, active citizens follow scripts and participate in scenes that are already created' (Isin 2008, p. 38). If we apply this principle to the Gängeviertel one can say that the activists 
of the Gängeviertel created a scene out of the cultural appropriation of the place and then used this as the stage to continuously recreate the scene. Out of an 'act of citizenship' (Isin 2008) diverse practices of performing citizenship were developed. With the help of these practices, they address their claims to the public and at the same time incorporate parts of the public sphere into the scene. To better understand this process, I refer to sociologist Erving Goffman, who argues that all social interactions between groups can be understood as performances on specific 'stages' that consist of:

front regions where a particular performance is or may be in progress, and back regions where action occurs that is related to the performance but inconsistent with the appearance fostered by the performance. (Goffman 1956, p. 82)

Furthermore, there is a third region that encompasses all places other than those defined as 'front' or 'back':

The notion of an outside region that is neither front nor back with respect to a particular performance conforms to our common-sense notion of social establishments, for when we look at most buildings we find within them rooms that are regularly or temporarily used as back regions and front regions, and we find that the outer walls of the building cut both types of rooms off from the outside world. (Goffman 1956, p. 82)

According to this model, the assignment of people to the three regions determines their role within social interactions. In case of the Gängeviertel, people from the outside region are invited to become part of the front and back region due to the openness of the place and its relatively inclusive decision-making structures. Borders between inside and outside are blurry and, therewith, social functions of activists, visitors and the public become entangled. Consequently, claims are not only articulated to, but also with and through the public; the Gängeviertel is the particular stage where these social interactions work successfully. Thereby place-specific aspects play a notably important role. In order to deepen our understanding about how people articulate claims successfully, we must take the conditions of the stage into account where new scenes of citizenship are created. Here, it is pertinent to refer to Lefebvre's concept of social space. 


\section{A Space of Performing Citizenship}

Henri Lefebvre's conceptualized space is an ongoing process of social production and reproduction, characterized by the interrelations of three equivalent dimensions: spatial practices, representations of space and spaces of representation (Lefebvre 1991). Lefebvre developed his theory out of the observation of long-term macrosociological processes. Nevertheless, his concept is applicable to smaller scale processes that take place within shorter timeframes- like the struggle over the Gängeviertel. ${ }^{11}$ If we apply his spatial triad to the articulation of claims in the Gängeviertel, one can understand all the practices of performing citizenship as a part of spatial practices. This dimension refers to the material foundation of space-like walls, buildings and streets - and also encompasses the everyday usage of material structures. Concerning the articulation of claims in the Gängeviertel, its many venues, galleries bars and cafés, the open building structure and the overall situation in the inner city of Hamburg are of particular importance. They weave the place into the fabric of urban life and so make it possible to reach a wide range of the public throughout the city. Moreover, the small-scale configuration of buildings supported the appropriation of the thirteen houses and the maintenance of selfmanagement structures that, still today, facilitate the many practices of performing citizenship in situ.

Representations of space refer to conceptualizations and planning, as well as the creation of images with the help of words, pictures and signs. Thus, all planning and concept work concerning the renovation and the development of the Gängeviertel should be seen as representations of space; additionally, publications, media reports and-on a more abstract level-the public discourse about the Gängeviertel, all refer to this dimension. It is far less based on the physical characteristics of the place because representations of space are largely produced outside of the Gängeviertelin planning offices, editorial departments, the public sphere and so on. Spaces of representation concern subjective imaginations that are connected to the space, along with the attribution of significance and associations of symbolic meanings to material objects. In case of the Gängeviertel, this dimension plays a particularly important role. The historic significance of the Gängeviertel appears to visitors through the building's historic materiality. Provisional outbuildings, art installations, street art and overall repair of the buildings all contribute toward an esthetic that gives expression to the self-management of the space. The walls of the Gängeviertel 
are carriers of meaning and stand in clear contrast to the appearance of the surrounding highly-priced and formalized real estate downtown. Thus, they function as a unique stage set for the ongoing performance happening within the place.

In the case of the Gängeviertel, the production of social space depends to a high degree on practices of performing citizenship that actually take place. The production of space intensively interrelates with the process of performing citizenship in all dimensions. Public articulations of demands contribute to the symbolic significance of the place. Politics of the city government and municipal development plans are crucial for the intensity and the design of practices of performing citizenship. Architectural planning of the renovation to some degree predetermines the esthetic of the place and its subjective perception by visitors. I assume that such spatial interrelations are of particular importance in understanding how practices and acts of claim-making unfold effectivity. This applies in particular to struggles with strong connection to specific places. The Gängeviertel activists are by now successful in asserting themselves against the city government because of the space they continue to create and hold. Here, they articulate claims to, with, and through the public. At the same time, they perform the rights they demand to some degree as they realize the selfmanagement of the place. In this way, they articulate their demands as the right to the city and put it into practice simultaneously.

As the case shows, to perform citizenship successfully might depend on the ability of citizens to open up and maintain a stage where they enact claims publicly, and effectively interrelate them with the preconditions of the place of claim-making, thus creating a space of performing citizenship. To have transformative impacts on the execution and design of rights, such spaces of performing citizenship have to establish a local social system that clearly differs from the society it is intertwined with. Such a space can unfold the power to challenge and question particular rights that shape society as it manifests a new social reality within a particular place.

\section{Notes}

1. 'Cultural appropriation' in this chapter stands for the peaceful appropriation of the abandoned houses with the help of cultural performances and artistic means. It fundamentally differs to current notions within the critical discourse on 'whiteness'. 
2. I use the term self-management following Henri Lefebvre's understanding (Lefebvre 1976, p. 120). As Neil Brenner puts it, self-management for Lefebvre connotes 'a political orientation through which various sectors of social life - from factories, universities, and political associations to territorial units such as cities and regions - might be subjected to new forms of decentralized, democratic political control through the very social actors who are most immediately attached to them' (Brenner 2008, p. 240).

3 . For more information about the Gängeviertel and a more detailed description of the cooperation process, see Ziehl 2016.

4. The cooperative was founded by the activists in 2010 in order to undertake the management of the houses from the municipality and the redevelopment agency. Members of the cooperative are required to make a minimum subscription of at least one share (500 Euro). Membership of the cooperative is not limited to the activists; supporters can also become members and participate in decision-making.

5. For more information about the protest of the Gängeviertel activists and their entanglement with the urban development policy of Hamburg, see Novy and Colomb 2013 and also Fraeser 2017.

6. Henri Lefebvre conceptualized the right to the city as follows: 'The right to the city, complemented by the right to difference and the right to information, should modify, concretize and make more practical the rights of the citizen as an urban dweller (citadin) and user of multiple services. It would affirm, on the one hand, the right of users to make known their ideas on the space and time of their activities in the urban area; it would also cover the right to the use of the center, a privileged place, instead of being dispersed and stuck in ghettos (for workers, immigrants, the "marginal" and even for the "privileged")' (Lefebvre, in Kofman and Lebas 1996, p. 34).

7. To fully meet the claim for the right to the city, it would not be enough to fundamentally change the current policy of the city government. Rather, a fundamental transformation of social, political, and economic structures would be necessary, with far-reaching consequences for processes of democratic decision-making and also the current notion of citizenship. Thus, claims concerning the right to the city often are connected to a national, if not global, scale. For a critical discussion of the relation between the right to the city, citizenship and representative democracy, see Purchell 2002. For more information about the 'Right to the City' network in Hamburg in the context of local urban development, see Birke 2016.

8. The cooperation agreement between several senators and the Gängeviertel activists is the fundament for the cooperation process and a unique piece of paper-there is no other example in Germany of a contract like this 
between a city government and organizations that developed out of an occupiers' movement.

9. For a press review of the Gängeviertel, see http://das-gaengeviertel.info/ medien/pressespiegel.html, date accessed 29 January 2018.

10. For the list of supporters, see http://das-gaengeviertel.info/nc/b/soli. html, date accessed 29 January 2018.

11. It is not my aim to analyze the spatial production process that takes place in the Gängeviertel in all its aspects; rather, I am briefly outlining the relations of the practices of performing citizenship and Lefebvre's three dimensions of space. Furthermore, within the limits of this chapter, I cannot go into detail about Lefebvre's complex concept; it has been discussed by several scholars in recent years. For a profound discussion see, for example, Schmid 2008.

\section{REFERENCES}

Birke, P. 2016. Right to the City- and Beyond. The Topographies of Urban Social Movements in Hamburg. In Urban Uprisings - Challenging Neoliberal Urbanism in Europe, ed. M. Mayer, C. Thörn, and H. Thörn, 203-232. New York: Palgrave Macmillan.

Brenner, N. 2008. Henri Lefebvre's Critique of State Productivism. In Space, Difference, Everyday Life - Reading Henri Lefebvre, ed. K. Goonewardena, S. Kipfer, R. Milgrom, and C. Schmid, 231-149. New York: Routledge.

Fraeser, N. 2017. Fantasies of Antithesis - Assessing Hamburg's Gängeviertel as a Tourist Attraction. In Protest and Resistance in the Tourist City, ed. C. Colomb and J. Novy, 320-339. London: Routledge.

Fraser, N. 2007. Transnationalizing the Public Sphere: On the Legitimacy and Efficacy of Public Opinion in a Post-Westphalian World. http://eipcp.net/ transversal/0605/fraser/en. Accessed 29 Jan 2018.

Goffman, E. 1956. The Presentation of Self in Everyday Life. Edinburgh: University of Edinburgh Social Sciences Research Centre.

Holston, J., and A. Appadurai. 1999. Cities and Citizenship. London: Duke University Press.

Isin, E.F. 2008. Theorizing Acts of Citizenship. In Acts of Citizenship, ed. E.F. Isin and G.M. Nielsen, 15-43. London: Zed Books.

Isin, E. 2017. Performative Citizenship. In Oxford Handbook of Citizenship, ed. A. Shachar, R. Bauböck, I. Bloemraad, and M. Vink, 500-523. Oxford: Oxford University Press.

Kofman, E., and E. Lebas. 1996. Lost in Transposition: Time, space, and the City. In Writings on Cities, ed. E. Kofman and E. Lebas, 3-60. Oxford: Blackwell.

Lefebvre, H. 1976. The Survival of Capitalism: Reproduction and the Relations of Production. New York: St. Martin's Press. 
1991. The Production of Space. Oxford: Blackwell.

Novy, J., and C. Colomb. 2013. Struggling for the Right to the (Creative) City in Berlin and Hamburg: New Urban Social Movements, New Spaces of Hope? International Journal of Urban and Regional Research 37 (5): 1816-1838.

Purchell, M. 2002. Excavating Lefebvre: The Right to the City and its Urban Politics of the Inhabitant. GeoJournal 58: 99-108.

Schmid, C. 2008. Henri Lefebvre's Theory of the Production of Space: Towards a Three-Dimensional Dialectic. In Space, Difference, Everyday Life-Reading Henri Lefebvre, ed. K. Goonewardena, S. Kipfer, R. Milgrom, and C. Schmid, 27-46. London: Routledge.

Ziehl, M. 2016. Cooperation with Resistance: The Development of the Gängeviertel in Hamburg. In City Linkage - Art and Culture Fostering Urban Futures, ed. T. Haupt, C. Rabe, and M. Ziehl, 75-85. Berlin: Jovis.

Ziemer, G. 2014. Urbane Öffentlichkeiten zwischen Kunst und Nichtkunst. Kollektive Dynamiken im Lauf der Zeit - am Beispiel des Gängeviertels. In Versammlung und Teilhabe. Urbane Öffentlichkeiten und performative Künste, ed. R. Burri, K. Evert, S. Peters, E. Pilkington, and G. Ziemer, 317-331. Bielefeld: Transcript.

Open Access This chapter is licensed under the terms of the Creative Commons Attribution 4.0 International License (http://creativecommons.org/licenses/ by $/ 4.0 /$ ), which permits use, sharing, adaptation, distribution and reproduction in any medium or format, as long as you give appropriate credit to the original author(s) and the source, provide a link to the Creative Commons licence and indicate if changes were made.

The images or other third party material in this chapter are included in the chapter's Creative Commons licence, unless indicated otherwise in a credit line to the material. If material is not included in the chapter's Creative Commons licence and your intended use is not permitted by statutory regulation or exceeds the permitted use, you will need to obtain permission directly from the copyright holder.

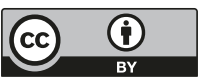

